University of Nebraska - Lincoln

DigitalCommons@University of Nebraska - Lincoln

Faculty Papers and Publications in Animal

Science

Animal Science Department

2002

\title{
Uncoupling proteins and energy expenditure in mice divergently selected for heat loss
}

T. G. McDaneld

University of Nebraska-Lincoln, tara.mcdaneld@ars.usda.gov

Merlyn K. Nielsen

University of Nebraska-Lincoln, mnielsen1@unl.edu

Jess Miner

University of Nebraska-Lincoln, jminer1@unl.edu

Follow this and additional works at: https://digitalcommons.unl.edu/animalscifacpub

Part of the Animal Sciences Commons

McDaneld, T. G.; Nielsen, Merlyn K.; and Miner, Jess, "Uncoupling proteins and energy expenditure in mice divergently selected for heat loss" (2002). Faculty Papers and Publications in Animal Science. 496.

https://digitalcommons.unl.edu/animalscifacpub/496

This Article is brought to you for free and open access by the Animal Science Department at DigitalCommons@University of Nebraska - Lincoln. It has been accepted for inclusion in Faculty Papers and Publications in Animal Science by an authorized administrator of DigitalCommons@University of Nebraska - Lincoln. 


\title{
Uncoupling proteins and energy expenditure in mice divergently selected for heat loss $^{1}$
}

\author{
T. G. McDaneld, M. K. Nielsen, and J. L. Miner ${ }^{2}$ \\ Department of Animal Science, University of Nebraska, Lincoln 68583-0908
}

\begin{abstract}
The objective of this study was to determine whether variation in energy expenditure created by selection on heat loss is mediated by uncoupling protein-1 (UCP1) in brown adipose tissue. Divergent selection for heat loss developed lines of mice with high $(\mathrm{MH})$ and low $(\mathrm{ML})$ maintenance energy expenditure. Concentration of UCP1 mRNA in brown adipose tissue (BAT) was $93 \%$ greater in ML than in $\mathrm{MH}$ mice $(P<$ 0.02 ). Two new lines of mice, $\mathrm{KH}$ and $\mathrm{KL}$, were bred by backcrossing a UCP1 knockout gene into the $\mathrm{MH}$
\end{abstract}

and ML lines, respectively; $\mathrm{KH}$ and $\mathrm{KL}$ with both knockout (-/-) and wild type (+/+) UCP1 genotypes were generated. At 13 wk of age, $\mathrm{KH}$ mice exhibited greater heat loss $\left(166 \mathrm{kcal} \cdot \mathrm{kg}^{0.75} \cdot \mathrm{d}^{-1}\right)$ than $\mathrm{KL}$ mice $(126.4 \mathrm{kcal} \cdot$ $\left.\mathrm{kg}^{0.75} \cdot \mathrm{d}^{-1}\right)$ regardless of the UCP1 knockout $(P<0.0001)$. Concentration of UCP2 mRNA in BAT was $74 \%$ greater in UCP1 knockout mice (-/-) than in wild type $(+/+; P$ $=0.0001)$. We conclude that response to selection for increased energy expenditure was not mediated by increased expression or function of UCP1.

Key Words: Brown Adipose Tissue, Food Intake, Heat Production, Obesity, UCP1, UCP2

(2002 American Society of Animal Science. All rights reserved.

J. Anim. Sci. 2002. 80:602-608

\section{Introduction}

Basal energy expenditure accounts for a majority of metabolizable energy intake in livestock (NRC, 1996). An understanding of the determinants of energy expenditure could improve agricultural efficiency and may improve human health via obesity prevention. Nielsen et al. (1997b) developed a mouse model to study energy expenditure. A composite population was created from four outbred strains including NIH, ICR, CF-1, and CFW. Sixteen generations of selection for high (MH) and low (ML) heat loss created lines that average 180 and $110 \mathrm{kcal} \cdot \mathrm{kg}^{0.75} \cdot \mathrm{d}^{-1}$, respectively. Body weight does not differ between the lines, but feed intake by $\mathrm{MH}$ mice is $23 \%$ greater than that by ML. Mice of the MH line are also leaner, display greater locomotor activity, and produce larger litters than ML mice (Jones et al., 1992; Nielsen et al., 1997a; Mousel et al., 2001).

Nonshivering thermogenesis in brown adipose tissue (BAT) can compensate for excessive caloric intake, thus

\footnotetext{
${ }^{1}$ This research was supported by National Science Foundation Grant No. LWF/31-559-20124, Nebraska EPSCoR (to J. Miner). This manuscript has been assigned journal series no. 13218, Agric. Res. Division, Univ. of Nebraska. We thank Jeryl Hauptman for skilled assistance in animal care, Mark Allan for providing mouse RNA, Scott Commins for technical advice, and Leslie Kozak for providing UCP1 knockout founder animals and for assistance in planning the experiments and review of the manuscript.

${ }^{2}$ Correspondence: phone: 402-472-0518; E-mail: jminer1@unl.edu. Received April 2, 2001.

Accepted October 16, 2001.
}

moderating obesity (Rothwell and Stock, 1979). Uncoupling protein-1 (UCP1) is specific to BAT and dissipates the mitochondrial proton gradient, thereby generating heat (Garlid et al., 1998). Thermogenesis may be mediated by UCP2, which is present in adults and is expressed in white adipose (WAT), skeletal muscle, heart, kidney, and lung (Fleury et al., 1997). The thermogenic properties of UCP2 are not established, but UCP2 mRNA is influenced by treatments that affect obesity, including conjugated linoleic acid and fibrate ligands (Tauboyama-Kasaoka et al., 1999; Nisoli et al., 2000). Perhaps thermogenesis mediated by UCP2 influences maintenance energy requirement of livestock.

Analysis of QTL did not implicate the UCP1 gene in the heat-production difference between $\mathrm{MH}$ and $\mathrm{ML}$ mice (Moody et al., 1999). However, UCP1 function depends on the endocrine and nervous systems. Given their heat production difference and the accepted function of UCP1, we hypothesized that UCP1 activity was changed during the development of $\mathrm{MH}$ and $\mathrm{ML}$ lines. Our objectives were to determine 1) whether expression of UCP1 and(or) UCP2 mRNA differed between the lines, 2) whether the heat loss difference between the lines depends on functional UCP1, and 3) whether incorporation of a UCP1 knockout influences UCP2 mRNA concentration in high- vs low- heat-loss selection lines.

\section{Materials and Methods}

Animal Protocol. Care and handling of animals was approved by the University of Nebraska Institutional 
Animal Care and Use Committee (protocol no. 98-04023). Heat-loss lines (MH and ML) and UCP1 knockout lines (KH and $\mathbf{K L}$ ) were in plastic cages at $22^{\circ} \mathrm{C}$ with no more than five mice per cage. The $\mathrm{KH}$ and $\mathrm{KL}$ dams were housed at $28^{\circ} \mathrm{C}$ from a few days before parturition until pups were weaned at $3 \mathrm{wk}$ of age to aid the survival of UCP1-knockout pups. After weaning, mice were given ad libitum access to a standard diet (4\% fat, 3.10 kcal/g, Harlan Teklad 8604, Madison, WI). Heat-loss lines and UCP1 knockout lines were killed by $\mathrm{CO}_{2}$ asphyxia at 12 and 13 wk of age, respectively. Body weights were measured and the following tissues were collected and weighed: BAT, gonadal WAT, retroperitoneal WAT, heart muscle, and skeletal muscle. Tissue selection was based on reported expression of UCP1 and UCP2 (Fleury et al., 1997). All tissues were frozen in liquid nitrogen and stored $\left(-80^{\circ} \mathrm{C}\right)$ until RNA extraction.

Preparation of Total RNA. Total RNA was extracted from 100-mg tissue samples (TRIZOL LS, Gibco, Gaithersburg, MD). Deoxyribonucleic acid contamination was removed by digestion with DNase (RQ1, Promega, Madison, WI). Purified RNA was stored in $\mathrm{H}_{2} \mathrm{O}$ at $-80^{\circ} \mathrm{C}$. Concentration of RNA was determined by fluorometry (TD-700; Turner Design, Sunnyvale, CA), using fluorescein excitation and emission wavelengths. Integrity of RNA was evaluated by visualizing 28 s and $18 \mathrm{~s}$ ribosomal bands on a $1 \%$ agarose gel (Sambrook et al., 1989).

UCP1 Riboprobe Templates. A 247-bp region of UCP1 cDNA was amplified by PCR using a linearized plasmid template (Kozak et al., 1988; GenBank U6341), and primers UCP1F559 (5'-TATTTATAGGATCCTGCCTCTCTCGGAA-3') and UCP1R806 (5'-ATTTGGATCGAGCTCTGTACAATTGATG-3'). The PCR product was digested with BamHI and HindIII, gel-purified, and ligated into a commercial plasmid (PGEM4Z, Promega) to generate a new plasmid (pTGM1MA). The PCR product was also digested with BamHI and SacI, then gelpurified and subcloned into PGEM 4Z (pTGM1MS). Sequences were verified by the University of Nebraska DNA sequencing core facility. Plasmid pTGM1MA was linearized with $S m a \mathrm{I}$ so that transcription driven by T7 promoter produced RNA antisense to UCP1 (nt 559 to nt 735). Plasmid pTGM1MS was linearized with EcoRI so that transcription driven by T7 promoter produced RNA sense to UCP1 (nt 559 to nt 806).

UCP2 Riboprobe Templates. Uncoupling protein-2 cDNA was digested with $\mathrm{BamHI}$ and the region composed of nt 807 to nt 1,136 was ligated into PGEM4Z (Fleury et al., 1997; GenBank U69135) to create pTGM2M. Digestion of pTGM2M with HincII allowed SP6-driven transcription of RNA antisense to UCP2. Digestion of pTGM2M with SmaI allows T7-driven transcription of RNA sense to UCP2. Both sense and antisense transcripts correspond to a 329-nt region of UCP2. This region of UCP2 was chosen because it lacks homology with UCP1.
Ribonuclease Protection Assays. Ribonucleic acid probes, including $\beta$-actin control, were transcribed with a commercial kit (RIBOPROBE, Promega). Ribonuclease protection assays (RPA) were adapted from a kit method (RPA II, Ambion, Austin, TX) as follows. The ${ }^{32} \mathrm{P}$-labeled probe $\left(100,000 \mathrm{dpm}, 4 \times 10^{8} \mathrm{dpm} / \mu \mathrm{g}\right)$ and total RNA were mixed with tRNA to a volume of $60 \mu \mathrm{L}$ (sample RNA plus tRNA $=40 \mu \mathrm{g}$ ) and coprecipitated with $16.25 \mu \mathrm{L} 7.5 \mathrm{M}$ ammonium acetate and $243.75 \mu \mathrm{L}$ ethanol at $-80^{\circ} \mathrm{C}$ for $15 \mathrm{~min}$. After centrifugation for $20 \mathrm{~min}$ at $12,000 \times \mathrm{g}$, pellets were resuspended in $30 \mu \mathrm{L}$ of hybridization buffer and incubated at $95^{\circ} \mathrm{C}$ for $5 \mathrm{~min}$ then at $48^{\circ} \mathrm{C}$ for $14 \mathrm{~h}$. Unhybridized RNA was digested with $225 \mathrm{U}$ RNase in $200 \mu \mathrm{L}$ of buffer at $37^{\circ} \mathrm{C}$ for $1 \mathrm{~h}$. Ethanol-precipitated pellets were resuspended in $8 \mu \mathrm{L}$ of loading buffer and electrophoresed on $6 \%$ SDS-PAGE. Gels were dried by vacuum. Phosphorimaging was used to analyze protected bands of hybridized regions for both UCP1 and UCP2 (Johnston et al., 1990; Molecular Dynamics, Sunyvale, CA). Radioactive signal for $\beta$-actin, UCP, and background was determined by creating boxes (all of the same size) around the specific bands and a region of the gel that did not contain a band. To quantify UCP1 and UCP2, a standard curve was generated using UCP1 and UCP2 sense RNA (Figure 1). The UCP1 and UCP2 signals were adjusted by dividing by $\beta$-actin signal.

Development of UCP1 Knockout Lines (KH and KL). To determine whether UCP1 mediates the difference in heat production between heat-loss selection lines, two new lines ( $\mathrm{KH}$ and $\mathrm{KL}$ ) were developed by incorporating a UCP1 knockout gene (Enerback et al., 1997). One male, heterozygous for the knockout of UCP1 (-/ +; provided by Leslie Kozak), was mated to $\mathrm{MH}$ and ML females. Uncoupling protein-1 knockout carrier (+/ -) males from each mating were backcrossed to inbred IH (line IH5) and IL (line IL8) females for five generations. The IH and IL are partially inbred lines of $\mathrm{MH}$ and ML, respectively (Allan et al., 2000). They were developed by repeated generations of full-sibling matings, seven of which were completed prior to our study (cumulative inbreeding estimated at $F=0.83$ ).

The protocol for identifying UCP1 alleles (knockout vs wild type) was as reported (Enerback et al., 1997). A $20-\mu \mathrm{L}$ PCR reaction including $1 \times$ buffer, $1.5 \mathrm{mM} \mathrm{MgCl}_{2}$, $200 \mathrm{n} M$ each dNTP, $200 \mathrm{n} M$ each primer (forward UCP8265，5'-GGTAGTATGCAAGAGAGGTGT-3'; reverse $\mathrm{Neo}$ re $\mathrm{Pr}$, 5'-CCTACCCGCTTGCATTGCTCA-3'; and reverse UCPrevE2, 5'-CCTAATGGTACTGGAAGCCTG-3'), 0.75 U Taq polymerase (Gibco), 0.75 $\mu \mathrm{L}$ loading buffer (REDILOAD, Research Genetics, Huntsville, AL), and 50 ng tail-clip DNA was subjected to thermal cycling: $94^{\circ} \mathrm{C}$ for $2 \mathrm{~min}\left(1\right.$ cycle); $94^{\circ} \mathrm{C}$ for $40 \mathrm{~s}, 60^{\circ} \mathrm{C}$ for $40 \mathrm{~s}, 72^{\circ} \mathrm{C}$ for $1 \mathrm{~min}(35$ cycles $)$; and $72^{\circ} \mathrm{C}$ for 5 min (1 cycle). Amplified DNA was $400 \mathrm{nt}$ if the knockout allele was present and $200 \mathrm{nt}$ if the wild type UCP1 allele was present.

Speed congenics was used to select animals with a bias to the IH and IL background (Wakeland et al., 
B
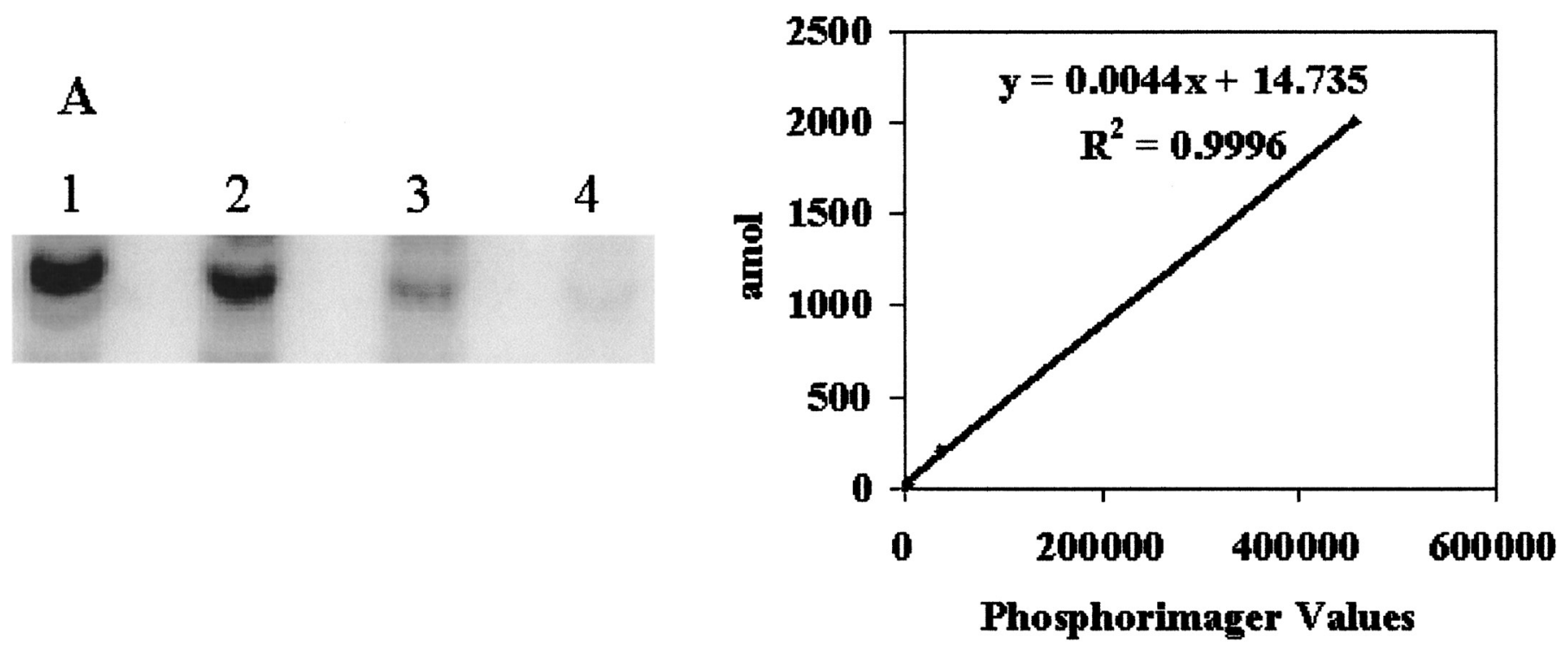

Figure 1. Standard curve for determining concentration of UCP mRNA. (A) Sense standard UCP1 RNA was hybridized with a fixed amount of UCP1 antisense probe. Lanes 1, 2, 3, and 4 resulted from hybridization with 2,000, 200, 20, and 2 amol, respectively. (B) The resulting standard curve was used to quantify UCP1 mRNA. A similar procedure was followed for determination of UCP1 and UCP2 in each assay.

1997). We used 25 informative markers concentrated in the chromosomes reported to harbor heat-loss QTL (Moody et al., 1999; Table 1). After the sixth generation, all typed markers in $\mathrm{KH}$ and $\mathrm{KL}$ were fixed to $\mathrm{IH}$ and IL background, respectively. Ten intermatings within $\mathrm{KH}$ and $\mathrm{KL}(+/-)$ generated the four strains: $\mathrm{KH}(-/-)$, $\mathrm{KH}(+/+), \mathrm{KL}(-/-)$, and $\mathrm{KL}(+/+)$. These male and female mice were used to determine whether the knockout of UCP1 mitigates the heat-production difference between the heat-loss lines.
Body Weight, Feed Intake, and Calorimetry in KH and $K L$ Lines. Body weight was determined weekly beginning at weaning ( $3 \mathrm{wk}$ ) and ending at $13 \mathrm{wk}$, when tissues were collected. Beginning at $9 \mathrm{wk}$, animals were housed individually and fed a meal diet (Harlan Teklad 8604) in feeders designed to limit spillage. Daily measurement of feed disappearance began at $10 \mathrm{wk}$ of age and continued for 5 to $7 \mathrm{~d}$.

Heat loss was measured by direct calorimetry as described by Nielsen et al. (1997b). Measurements were

Table 1. Microsatelite markers used for speed congenics in backcrossing of knockout lines ( $\mathrm{KH}$ and $\mathrm{KL})$, corresponding chromosomal positions (cM, in Haldane units), and generation (Gen) fixed ${ }^{\mathrm{a}}$

\begin{tabular}{lrclcclcc}
\hline \hline Marker & \multicolumn{1}{c}{ cM } & Gen & Marker & cM & Gen & Marker & cM & Gen \\
\hline D1Mit67 & 9.0 & 4 & D3Mit293 & 80.6 & 5 & D7Mit105 & 65.7 & 6 \\
D1Mit155 & 135.7 & 5 & D3Mit305 & 11.2 & 5 & D7Mit270 & 18.0 & 5 \\
D1Mit303 & 48.1 & 4 & D4Mit164 & 37.4 & 5 & D8Mit94 & 13.0 & 6 \\
D1Mit407 & 122.9 & 5 & D4Mit189 & 103.7 & 5 & D8Mit236 & 36.0 & 6 \\
D3Mit164 & & 5 & D5Mit188 & 54.8 & 4 & D8Mit242 & 40.6 & 6 \\
D3Mit189 & & 5 & D5Mit352 & 20.0 & 5 & D9Mit243 & & 6 \\
D3Mit193 & 71.4 & 5 & D6Mit254 & 62.6 & 5 & D9Mit302 & 39.8 & 6 \\
D3Mit227 & 23.5 & 5 & D7Mit62 & 40.7 & 4 & D9Mit328 & 23.0 & 6 \\
& & & & & & D10Mit233 & 62.2 & 6 \\
\hline
\end{tabular}

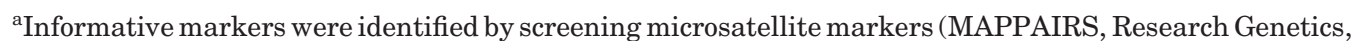
Huntsville, AL) in inbred heat loss (IH and IL) and founder mice. Genotypes were identified by examination of PCR products on ethidium bromide-stained 4\% agarose gels (METAPHORE, FMC BioProducts, Rockland, ME). A 10- $\mu \mathrm{L}$ PCR reaction including $1 \times$ buffer, $1.5 \mathrm{~m} M \mathrm{MgCl}_{2}, 200 \mathrm{n} M$ each dNTP, $200 \mathrm{n} M$ forward and reverse primer, $0.375 \mathrm{U} T a q$ polymerase, $0.75 \mu \mathrm{L}$ REDILOAD, and $50 \mathrm{ng}$ DNA was subjected to thermal cycling: $94^{\circ} \mathrm{C}$ for $3 \mathrm{~min}(1 \mathrm{cycle}) ; 72^{\circ} \mathrm{C}$ for $2 \mathrm{~min}\left(1\right.$ cycle); $94^{\circ} \mathrm{C}$ for $15 \mathrm{~s}, 55^{\circ} \mathrm{C}$ for $30 \mathrm{~s}, 72^{\circ} \mathrm{C}$ for $30 \mathrm{~s}(39$ cycles); and $72^{\circ} \mathrm{C}$ for 2 min ( 1 cycle). 
made at 10 to $12 \mathrm{wk}$ using individual-animal, direct calorimeters, and ambient temperature of $25^{\circ} \mathrm{C}$. Mice were placed in the calorimeters at 1600 and provided $9 \mathrm{~g}$ of feed. After a 30-min adjustment period, heat loss was recorded each minute and averaged for $15 \mathrm{~h}$. Mice were removed from the calorimeters in the morning and orts were weighed.

Statistical Analyses. Concentrations of mRNA were subjected to analysis of variance (SAS Inst. Inc., Cary, $\mathrm{NC}$ ). The model used for analysis of MH vs ML included only the main effect of line. Model effects for UCP1 knockout lines included line (KH vs KL), sex, UCP1 genotype (-/- vs +/+), and all interactions. Heat production and feed intake were adjusted to metabolic body size $\left(\mathrm{kg}^{0.75}\right)$ and then were analyzed using a fixed model procedure (PROC GLM). Model effects included line, sex, UCP1 genotype, and all interactions. The model used to analyze tissue weights additionally included mouse body weight as a covariate. Weekly body weight data for each mouse were fitted to a nonlinear growth model. The model was: weight at week $\mathrm{w}=\mathrm{wt} \max /(1+$ $\mathrm{kt} / \mathrm{w}$ ), where wt max and kt are unknown and represent maximum weight and maturing rate, respectively. Then wt max and kt estimates for each mouse were analyzed using a fixed model with line, UPC1 genotype, sex, and all interactions in PROC GLM. Daily feed intake data were analyzed using a mixed model procedure (SAS; Littell et al., 1996); fixed effects in the model were line, sex, UCP1 genotype, and all interactions and animal was the random effect in addition to random error.

\section{Results}

UCP Expression in Mice Selected for Heat Loss ( $M H$ and $M L)$. Concentration of UCP1 mRNA was $93 \%$ greater in BAT of the low-heat-loss line (ML) than in BAT of the high-heat-loss line (MH) $(P<0.05$; Figure 2 ), confirmed in two independent experiments. This contrasts with our expectation that the mice that produce more heat would express more UCP1. Uncoupling protein-2 mRNA concentrations in $\mathrm{MH}$ and ML did not differ $(P>0.15)$ in BAT, gonadal WAT, skeletal muscle, or heart muscle (Table 2). Therefore, it does not seem that the greater energy expenditure in $\mathrm{MH}$ mice is due to increased expression of either UCP1 or UCP2. However, a lack of difference in UCP mRNA concentration does not, by itself, rule out a potential difference in UCP-mediated thermogenesis. Thus, we next determined the effect of a UCP1-knockout allele in the two heat-loss selection lines.

UCP1-Knockout in Heat-Loss Lines (KH and KL). Incorporation of the UCP1-knockout gene did not affect heat loss in either the high- $(\mathrm{KH})$ or the low- (KL) heatloss line $(P>0.4$; Table 3$)$. Heat production differed between the two lines, but there was no interaction of line $\times$ UCP1 genotype $(P>0.5)$. Similarly, feed intake was greater for $\mathrm{KH}$ than for KL but was not influenced by UCP1 genotype. At 13 wk of age, body weight of KH

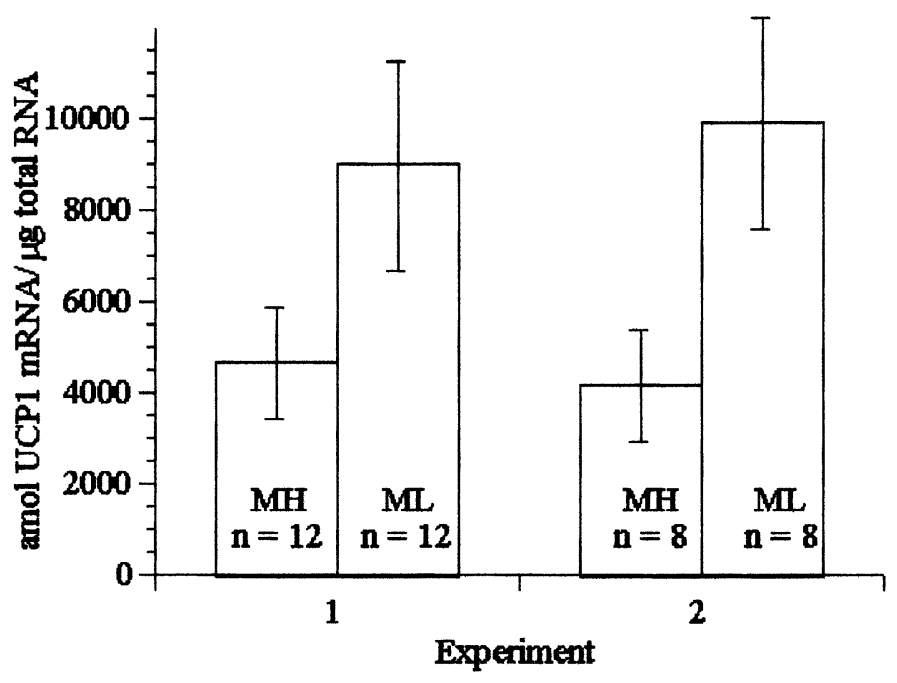

Figure 2. Concentration of UCP1 mRNA in brown adipose tissue of high- $(\mathrm{MH})$ and low- $(\mathrm{ML})$ heat-loss lines. In two independent experiments, BAT samples were obtained from male mice approximately $12 \mathrm{wk}$ of age. Total RNA $(2.5 \mu \mathrm{g})$ from each mouse was assayed independently. Effect of mouse line in each experiment $(P<0.05)$.

mice was significantly heavier than that of KL mice (Table 3 and Figure 3; $P<0.0001$ ), but neither UCP1 genotype nor its interaction with line was significant. The KH mice had heavier BAT pads than KL mice, and the knockout of UCP1 caused a greater increase in BAT weight in $\mathrm{KH}$ than in $\mathrm{KL}$ mice $(P<0.05$; Table 3$)$. Uncoupling protein-1 genotype did not influence gonadal WAT weight, retroperitoneal WAT weight, or heart weight. However, a line $\times \mathrm{UCP} 1$ genotype interaction was detected for heart weight $(P<0.05)$; the knockout of UCP1 increased weight of hearts in KL but decreased heart weight in KH (Table 3).

The concentration of UCP1 mRNA was greater in BAT of $\mathrm{KL}(+/+)$ than in BAT of $\mathrm{KH}(+/+)$ mice $(P<0.01$; Figure 4), which compares favorably with the observed difference between MH and ML mice (see above). No UCP1 mRNA was detected in samples derived from UCP1 knockout mice. Significantly more UCP2 mRNA was found in BAT of UCP1 (-l-) mice than in BAT of UCP1 (+/+) mice (Table 4), although this effect of UCP1 knockout was similar in $\mathrm{KH}$ and $\mathrm{KL}$ lines $(P<0.0001)$. No effect of either line or UCP1 genotype was detected for UCP2 mRNA in gonadal WAT, skeletal muscle, or heart muscle.

\section{Discussion}

The MH and ML lines that we studied had been generated by imposing divergent selection in an outbred founder population (Nielsen et al., 1997b). Thus, both $\mathrm{MH}$ and ML mice were derived from one heterogeneous genetic background. After 16 generations of selection, the $\mathrm{MH}$ line is distinct from the ML line. The $\mathrm{MH}$ mice generate at least 50\% more heat than ML mice, con- 
Table 2. UCP2 mRNA concentration (amol/ $\mu$ g total RNA, least squares means) in mice selected for high (MH) and low (ML) heat loss

\begin{tabular}{lccrc}
\hline \hline Tissue & MH & ML & SEM & $P$-value \\
\hline BAT $^{\mathrm{a}}$ & $139.6(\mathrm{n}=7)$ & $78.0(\mathrm{n}=8)$ & 25.8 & $\mathrm{NS}^{\mathrm{b}}$ \\
Gonadal WAT & $43.0(\mathrm{n}=8)$ & $35.2(\mathrm{n}=8)$ & 4.1 & $\mathrm{NS}$ \\
Skeletal muscle & $7.9(\mathrm{n}=10)$ & $5.7(\mathrm{n}=9)$ & 3.6 & $\mathrm{NS}$ \\
Heart muscle & $116.2(\mathrm{n}=11)$ & $115.5(\mathrm{n}=11)$ & 3.0 & $\mathrm{NS}$ \\
\hline
\end{tabular}

${ }^{\mathrm{a}} \mathrm{BAT}=$ brown adipose tissue.

${ }^{\mathrm{b}} \mathrm{NS}=$ nonsignificant $(P>0.10)$.

${ }^{\mathrm{c}} \mathrm{WAT}=$ white adipose tissue.

sume $20 \%$ more feed, average two more pups per litter, and are 35\% leaner (Moody et al., 1997, 1999). Our hypothesis was that concentration of UCP1 mRNA would be elevated in MH compared to ML mice. However, we observed the opposite. The mice in the lowheat-loss line exhibited significantly more UCP1 mRNA in brown fat than did $\mathrm{MH}$ mice. Uncoupling protein-2 mRNA content was similar between the lines. These observations do not support the hypothesis that $\mathrm{MH}$ and ML mice differ in energy expenditure because of UCP1 or UCP2. We also expected that inactivation of the UCP1 gene would eliminate, or at least reduce, the difference in heat production between these two lines. Instead, backcrossing a UCP1 knockout allele had no effect on the difference in heat production between the lines. It seems that the $\mathrm{MH}$ and ML lines differ in energy expenditure because of mechanisms independent of UCP1-mediated thermogenesis. Certainly, the heat-loss difference between these lines does not depend on UCP1 mRNA concentration.

At least part of the difference in heat loss between MH and ML mice is due to locomotor activity (Jones and Miner, 2000; Mousel et al., 2001). The MH mice are significantly more active, especially during the light phase when the ML mice, and most other mice, tend to rest. Perhaps the elevated physical activity of $\mathrm{MH}$ mice supercedes regulation of BAT thermogenesis for maintenance of body temperature. If so, this may ex- plain why UCP1 mRNA concentration is lower in $\mathrm{MH}$ than in ML mice.

Although heat loss was not changed by the UCP1 knockout allele (-/-), mice within this allele did have increased weight of BAT and concentration of UCP2 mRNA in BAT, as previously reported (Enerback et al., 1997). We further noticed that the color of BAT from UCP1 knockout mice was darker and more red, which could reflect increased mitochondrial concentration and(or) vascularity. Presumably, these adaptations are an attempt to compensate for loss of UCP1 function. Whether these changes are associated with compensatory thermogenesis in BAT is questionable. Matthias et al. (1999) reported that elevation of UCP2 mRNA in brown adipocytes did not by itself lead to de-energization of the mitochondrial membrane. Also, adrenergically stimulated thermogenesis in brown adipocytes is completely dependent on presence of UCP1, regardless of UCP2 or UCP3 status (Matthias et al., 2000).

The greater body weight and(or) retroperitoneal fat of $\mathrm{KH}$ vs KL mice at $13 \mathrm{wk}$ of age differed from previous observations that $\mathrm{MH}$ and ML mice are equal in weight at this age (Moody et al., 1997; Nielsen et al., 1997a). The reason for a body weight difference between $\mathrm{KH}$ and KL mice may be due to genetic drift during development of the inbred IH and IL lines; one would expect an inbred line to vary from its foundation in at least some traits (Falconer and Mackay, 1996). Alternately,

Table 3. Heat loss, feed intake, and tissue weights of UCP1 knockout $(-/-)$ and wild type $(+/+)$ mice in the high- $(\mathrm{KH})$ and low- $(\mathrm{KL})$ heat-loss selection lines ${ }^{\mathrm{a}}$

\begin{tabular}{|c|c|c|c|c|c|}
\hline \multirow[b]{2}{*}{ Measurement ${ }^{\mathrm{b}}$} & \multicolumn{2}{|c|}{$\mathrm{KH}$} & \multicolumn{2}{|c|}{ KL } & \multirow[b]{2}{*}{ Test $^{\mathrm{c}}$} \\
\hline & $-1-$ & $+/+$ & $-1-$ & $+/+$ & \\
\hline Heat loss, $\mathrm{kcal} \cdot \mathrm{kg}^{-0.75} \cdot \mathrm{d}^{-1}$ & $164 \pm 3$ & $168 \pm 5$ & $127 \pm 3$ & $125 \pm 6$ & $\mathrm{~L}$ \\
\hline Feed intake, $\mathrm{g} \cdot \mathrm{kg}^{0.75} \cdot \mathrm{d}^{-1}$ & $74.3 \pm 1.0$ & $74.1 \pm 1.4$ & $66.2 \pm 1.1$ & $70.3 \pm 2.1$ & $\mathrm{~L}$ \\
\hline Body weight, $\mathrm{g}$ & $31.0 \pm 0.35$ & $31.4 \pm 0.48$ & $26.7 \pm 0.38$ & $25.4 \pm 0.63$ & $\mathrm{~L}$ \\
\hline BAT weight, mg & $360 \pm 12$ & $180 \pm 17$ & $280 \pm 15$ & $170 \pm 24$ & $\mathrm{~L}, \mathrm{G}, \mathrm{I}$ \\
\hline GWAT weight, mg & $260 \pm 11$ & $240 \pm 15$ & $210 \pm 13$ & $240 \pm 21$ & $\mathrm{NS}^{\mathrm{d}}$ \\
\hline RWAT weight, mg & $32 \pm 2$ & $27 \pm 2$ & $21 \pm 2$ & $20 \pm 2$ & $\mathrm{~L}$ \\
\hline Heart weight, mg & $170 \pm 4$ & $180 \pm 5$ & $160 \pm 5$ & $150 \pm 8$ & $\mathrm{~L}, \mathrm{I}$ \\
\hline
\end{tabular}

\footnotetext{
aAnimal numbers were: $\mathrm{KH}(-/-)=39, \mathrm{KH}(+/+)=13, \mathrm{KL}(-/-)=31$, and $\mathrm{KL}(+/+)=9$.

${ }^{b}$ Values are least squares means \pm SEM. GWAT $=$ gonadal white adipose tissue. RWAT $=$ retroperitoneal white adipose tissue. Tissue weights were analyzed with body weight as a covariate.

${ }^{c} \mathrm{~L}, \mathrm{G}$, and I indicate $P<0.05$ for line, UCP1 genotype, and line $\times$ genotype interaction, respectively.

${ }^{\mathrm{d}} \mathrm{NS}=$ nonsignificant $(P>0.10)$.
} 


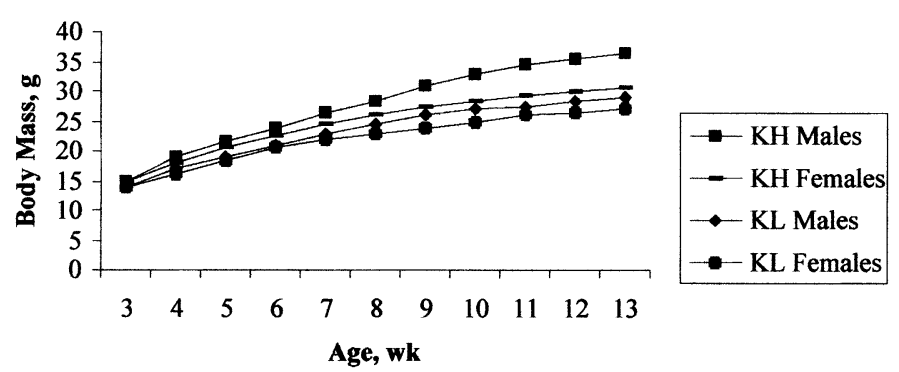

Figure 3. Weekly body weights for male and female mice from heat-loss selection lines, pooled over UCP1 $(-/-)$ and UCP1 $(+/+)$ because UCP1 genotype was not significant. Effect of sex $(P<0.0001)$ and line $(P<0.0001)$ at wk 13.

it is possible that the $\mathrm{KL}$ line retained a greater proportion of the founder male's genotype. The UCP1 knockout founder male was of C57BL/6J and 129/SvPas background. The C57BL/6J is smaller and leaner than $\mathrm{MH}$ or ML (Moody et al., 1997). However, $98.4 \%$ of the KH and $\mathrm{KL}$ background was derived from $\mathrm{MH}$ and $\mathrm{ML}$, respectively, and this proportion was greater yet in the 10 chromosomes to which speed congenics was applied (Wakeland et al., 1997). Furthermore, the comparison of UCP1 (-/-) with UCP1 (+/+) was not likely compromised by the retention of DNA from the founder male because both UCP1 genotypes were studied in the same background; they were siblings from the same litters.

We conclude that UCP1-mediated thermogenesis does not explain the energy expenditure divergence between the $\mathrm{MH}$ and ML lines.

\section{Implications}

Genetic selection for energy expenditure apparently does not influence heat loss via nonshivering thermogenesis in brown adipose tissue. This implies that the mouse is relevant for study of genetic effects on maintenance energy in livestock, and its understanding may
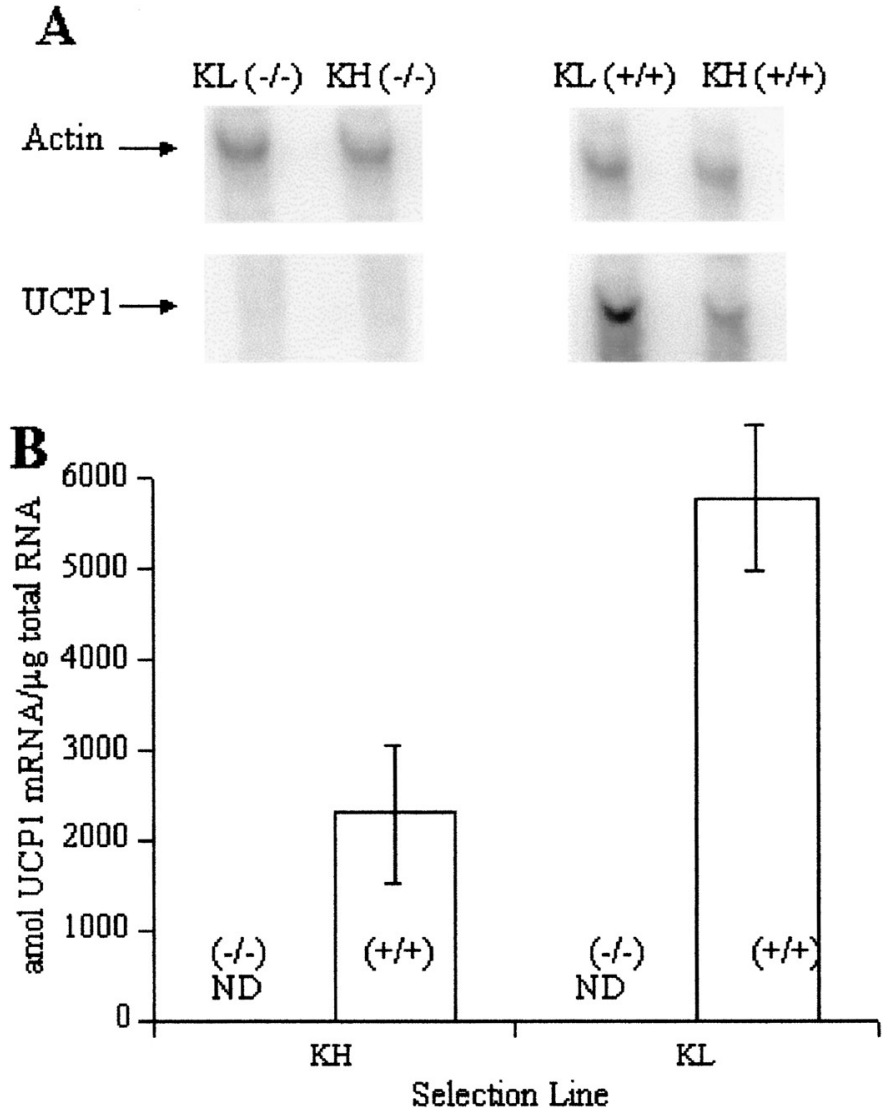

Figure 4. Ribonuclease protection assay for UCP1 mRNA concentration in $10 \mu \mathrm{g}$ of brown adipose tissue RNA of murine UCP1-knockout lines. The UCP1 mRNA were adjusted to a constant $\beta$-actin mRNA basis. There was no detectable (ND) UCP1 mRNA for KL and KH (-/ $-)$. The KL $(+/+)$ exhibited greater concentration of UCP1 mRNA than $\mathrm{KH}(+/+; P<0.004)$. Animals per line were $\mathrm{KL}(-/-)=28, \mathrm{KH}(-/-)=27, \mathrm{KL}(+/+)=15$, and $\mathrm{KH}(+/$ $+)=26$. (A) Example of signal from one animal per class. (B) Least squares means \pm SEM.

Table 4. UCP2 mRNA concentration (amol/ $\mu \mathrm{g}$ total RNA) of UCP1 knockout (-/-) and wild type $(+/+)$ mice in the high- $(\mathrm{KH})$ and low- $(\mathrm{KL})$ heat-loss selection lines ${ }^{\mathrm{a}}$

\begin{tabular}{|c|c|c|c|c|c|}
\hline \multirow[b]{2}{*}{ Tissue } & \multicolumn{2}{|c|}{$\mathrm{KH}$} & \multicolumn{2}{|c|}{$\mathrm{KL}$} & \multirow[b]{2}{*}{ Test $^{\mathrm{b}}$} \\
\hline & $-1-$ & $+/+$ & $-1-$ & $+/+$ & \\
\hline BAT & $\begin{array}{c}368.9 \pm 26.0 \\
(\mathrm{n}=27)\end{array}$ & $\begin{array}{c}235.7 \pm 32.1 \\
\quad(\mathrm{n}=28)\end{array}$ & $\begin{array}{c}440.2 \pm 26.8 \\
(\mathrm{n}=22)\end{array}$ & $\begin{array}{c}230.2 \pm 33.3 \\
(\mathrm{n}=14)\end{array}$ & G \\
\hline Gonadal WAT & $\begin{array}{c}67.4 \pm 5.5 \\
(\mathrm{n}=26)\end{array}$ & $\begin{array}{c}75.1 \pm 8.6 \\
(\mathrm{n}=23)\end{array}$ & $\begin{array}{c}73.6 \pm 6.3 \\
(\mathrm{n}=11)\end{array}$ & $\begin{array}{c}74.2 \pm 9.4 \\
(\mathrm{n}=7)\end{array}$ & NS \\
\hline Skeletal muscle & $\begin{array}{l}2.4 \pm 1.5 \\
(\mathrm{n}=28)\end{array}$ & $\begin{array}{l}5.1 \pm 2.0 \\
(\mathrm{n}=26)\end{array}$ & $\begin{array}{l}4.7 \pm 1.5 \\
(\mathrm{n}=16)\end{array}$ & $\begin{array}{l}5.3 \pm 2.4 \\
(\mathrm{n}=10)\end{array}$ & NS \\
\hline Heart muscle & $\begin{array}{c}106.7 \pm 2.8 \\
(\mathrm{n}=36)\end{array}$ & $\begin{array}{c}102.3 \pm 3.8 \\
(\mathrm{n}=20)\end{array}$ & $\begin{array}{c}101.4 \pm 3.2 \\
(\mathrm{n}=20)\end{array}$ & $\begin{array}{c}95.3 \pm 4.6 \\
(\mathrm{n}=11)\end{array}$ & NS \\
\hline
\end{tabular}

${ }^{a}$ Values are means \pm SEM. Tissue weights were analyzed using body weight as a covariate.

${ }^{\mathrm{b}} \mathrm{G}$ indicates main effect of UCP1 genotype $(P<0.0001)$; NS indicates no effect detected for selection line, UCP1 genotype, or interaction of selection line by UCP1 genotype, $P>0.10$. 
be applicable to species that do not maintain appreciable brown adipose tissue.

\section{Literature Cited}

Allan, M. F., M. K. Nielsen, and D. Pomp. 2000. Gene expression in hypothalamus and brown adipose tissue of mice divergently selected for heat loss. Physiol. Genomics 3:149-156.

Enerback, S., A. Jacobsson, E. M. Simpson, C. Guerra, H. Yamashita, M. Harper, and L. P. Kozak. 1997. Mice lacking mitochondrial uncoupling protein are cold-sensitive but not obese. Nature (Lond.) 387:90-94.

Falconer, D. S., and T. F. C. Mackay. 1996. Introduction to Quantitative Genetics. p 52. Addison Wesley Longman Ltd., Essex, U.K.

Fleury, C., M. Neverova, S. Collins, S. Raimbault, O. Champigny, C. Levi-Meyrueis, F. Bouilaud, M. Seldin, R. S. Surwit, D. Ricquier, and C. H. Warden. 1997. Uncoupling protein-2: A novel gene linked to obesity and hyperinsulinemia. Nature (Lond.) 15:269-272.

Garlid, K. D., M. Jaburek, and P. Jezek. 1998. The mechanism of proton transport mediated by mitochondrial uncoupling proteins. FEBS Lett. 438:10-14.

Johnston, R. F., S. C. Pickett, and D. L. Barker. 1990. Autoradiography using storage phosphor technology. Electrophoresis $11: 355-360$

Jones, J. G., and J. L. Miner. 2000. Behavior of mice selected for high and low heat loss during light and dark photoperiods. J. Anim. Sci. 78(Suppl. 2):50 (Abstr.).

Jones, L. D., M. K. Nielsen, and R. A. Britton. 1992. Genetic variation in liver mass, body mass, and liver:body mass in mice. J. Anim. Sci. 70:2999-3006.

Kozak, L. P., J. H. Britton, U. C. Kozak, and J. M. Wells. 1988. The mitochondrial uncoupling protein gene. J. Biol. Chem. 263:12274-12277.

Littell, R. C., G. A. Milliken, W. W. Stroup, and R. D. Wolfinger. 1996. SAS System for Mixed Models. SAS Inst. Inc., Cary, NC.

Matthias, A., A. Jacobsson, B. Cannon, and J. Nedergaard. 1999. The bioenergetics of brown fat mitochondria from UCP1-ablated mice. J. Biol. Chem. 274:28150-28160.
Matthias, A., K. B. E. Ohlson, J. M. Fredriksson, A. Jacobsson, J. Nedergaard, and B. Cannon. 2000. Thermogenic responses in brown fat cells are fully UCP1-dependent. J. Biol. Chem. 275:25073-25081.

Moody, D. E., D. Pomp, and M. K. Nielsen. 1997. Variability in metabolic rate, feed intake and fatness among selection and inbred lines of mice. Genet. Res. 70:225-235.

Moody, D. E., D. Pomp, M. K. Nielsen, and L. D. Van Vleck. 1999. Identification of quantitative trait loci influencing traits related to energy balance in selection and inbred lines of mice. Genetics 152:699-711.

Mousel, M. R., W. W. Stroup, and M. K. Nielsen. 2001. Locomotor activity, core body temperature and circadian rhythms in mice selected for high and low heat loss. J. Anim. Sci. 79:861-868.

NRC. 1996. Nutrient Requirements of Beef Cattle. 7th ed. National Academy Press, Washington, DC.

Nielsen, M. K., B. A. Freking, L. D. Jones, S. M. Nelson, T. L. Vorderstrasse, and B. A. Hussey. 1997a. Divergent selection for heat loss in mice: II. Correlated responses in feed intake, body mass, body composition, and number born through fifteen generations. J. Anim. Sci. 75:1469-1476.

Nielsen, M. K., L. D. Jones, B. A. Freking, and J. A. DeShazer. 1997b. Divergent selection for heat loss in mice: I. Selection applied and direct response through fifteen generations. J. Anim. Sci. 75:1461-1468.

Nisoli, E., M. O. Carruba, C. Tonello, C. Macor, G. Federspil, and R. Vettor. 2000. Induction of fatty acid translocase/CD36, peroxisome proliferator-activated receptor-gamma 2, leptin, uncoupling proteins 2 and 3, and tumor necrosis factor-alpha gene expression in human subcutaneous fat by lipid infusion. Diabetes 49:319-324.

Rothwell, N. J., and M. J. Stock. 1979. A role for brown adipose tissue in diet-induced thermogenesis. Nature (Lond.) 281:31-35.

Sambrook, J., E. F. Fritsch, and T. Maniatis. 1989. Molecular Cloning. Cold Spring Harbor Press, Cold Spring Harbor, NY.

Tsuboyama-Kasaoka, N., M. Takahashi, H. Kim, and O. Ezaki. 1999. Up-regulation of liver uncoupling protein-2 mRNA by either fish oil feeding or fibrate administration in mice. Biochem. Biophys. Res. Commun. 257:879-885.

Wakeland, E., L. Morel, K. Achey, M. Yui, and J. Longmate. 1997. Speed congenics: a classic technique in the fast lane (relatively speaking). Immunol. Today 18:472-477. 